\title{
Spatio-Temporal Dynamic of Land Use in the Dja-Odzala-Minkébé Landscape between Cameroon, Congo and Gabon: Influence on the Evolution of Forest Cover in a Context of Cross-Border Cooperation
}

\author{
Martin Tadoum ${ }^{1 *}$, Martin Tchamba ${ }^{2,3}$, Armand Tanougong 3,4 \\ ${ }^{1}$ Panafrican Institute for Development (PAID), Yaoundé, Cameroon \\ ${ }^{2}$ Department of Forestry, Faculty of Agronomy and Agricultural Sciences, University of Dschang, Dschang, Cameroun \\ ${ }^{3}$ Laboratory of Environmental Geomatic, Faculty of Agronomy and Agricultural Sciences, University of Dschang, Dschang, \\ Cameroun \\ ${ }^{4}$ FokabsInc, PO Box: 955 Rotary Way, K1T 0L2 Ottawa ON, Canada \\ Email: *martintadoum@gmail.com
}

How to cite this paper: Tadoum, M., Tchamba, M., \& Tanougong, A. (2021). Spatio-Temporal Dynamic of Land Use in the Dja-Odzala-Minkébé Landscape between Cameroon, Congo and Gabon: Influence on the Evolution of Forest Cover in a Context of Cross-Border Cooperation. Open Journal of Forestry, 11, 222-237.

https://doi.org/10.4236/ojf.2021.113015

Received: April 28, 2021

Accepted: June 15, 2021

Published: June 18, 2021

Copyright $\odot 2021$ by author(s) and Scientific Research Publishing Inc. This work is licensed under the Creative Commons Attribution International License (CC BY 4.0).

http://creativecommons.org/licenses/by/4.0/

\begin{abstract}
This study is being carried out in the cross-border area of the tri-national Dja-Odzala-Minkébé (TRIDOM), subject of a cooperation agreement between Cameroon, Congo and Gabon in 2005. The purpose of this study is to analyze the dynamics of changes in land use in the context of cross-border cooperation. Geographic information systems and remote sensing were used to produce the various land use maps. For this purpose, the MERIS satellite images for the periods 1992, 2005 and 2018 were used. The exploration of the different images and the field visits made it possible to identify the following six land use classes: dense forests, degraded/deforested forests, savannas, swamp forests, buildings and bare soils, water surfaces. It emerges that the TRIDOM landscape is mainly occupied by dense forests which represent 97.02\%, 96.72\% and 96.52\% respectively in 1992, 2005 and 2018. Then, degraded/deforested forests and savannas which would correspond to cultivation areas and fallow land only represent respectively $1.06 \%$ and $0.68 \%$ of the landscape in 1992. This proportion in 2005 is respectively $1.22 \%$ and $0.77 \%$, whereas in 2018 , it is respectively $1.36 \%$ and $0.81 \%$ of the massif. The landscape of TRIDOM has not experienced any significant land use change during the period after the signing of the cooperation agreement. Historical rates of deforestation are low during the period under study. They are estimated at $0.042 \%$ and $0.030 \%$ respectively for the period $1992-2005$ and the period
\end{abstract}


2005-2018. These low rates of deforestation seem to be due to the measures taken to secure and sustainably manage the massif taken by the three countries, the low population density in this area and the still difficult level of accessibility of a large part of the massif.

\section{Keywords}

Cross-Border Area, Cooperation Agreement, Land Use, Forest Covert, TRIDOM

\section{Introduction}

Central Africa is home to the second largest expanse of dense and humid forests on the planet after the Amazon. Indeed, these forests, covering an area of approximately 2 million km² (Mayaux et al., 1998 cited by Ernst et al., 2010) cover most of the Congo Basin, extending from the Gulf of Guinea to the west to the Albertine rift in the east. These exceptionally rich forests are the subject of many threats. These threats relate to unsustainable and illegal logging, shifting slashand-burn agriculture and intensive agriculture in densely populated areas, animal poaching, exploration and mining.

To preserve this forest heritage, the political leaders of the countries of Central Africa are committed to working in a concerted manner within the framework of sub-regional and cross-border cooperation processes. To this end, several complexes of cross-border protected areas have been set up. This is the case of the complex of transboundary protected areas Dja-Odzala-Minkébé commonly called tri-national Dja-Odzala-Minkébé for short TRIDOM between Cameroon, Congo and Gabon. TRIDOM covers an area of approximately 191,541 km² (De Wachter et al., 2008), which corresponds to $10 \%$ of the forest area of the Congo Basin. It is one of the still relatively intact forest areas and one of the last refuges for large fauna in the Congo Basin. It has nine protected areas and a large interzone comprising forest production areas, sport hunting areas, community hunting areas, agro-forestry areas and mining areas.

With a view to the concerted and sustainable management of natural resources in this area, the political authorities of the three countries concluded a cooperation agreement in 2005. The stated objective of this cooperation agreement is to set up and manage in partnership, the transboundary complex of protected areas Dja-Odzala-Minkébé and its interzone in order to promote conservation, rational use of natural resources and sustainable development for the benefit of local communities in order to contribute to poverty reduction.

The TRIDOM cross-border area faces major challenges linked, among other things, to the concurrent use of land, which threatens the sustainability of this forest area. Indeed, several actors with sometimes divergent objectives, interact in this space either for the exploitation of natural resources or for the conservation of biodiversity. Such competing uses lead to problems of land use conflicts. In fact, due to the presence of significant mineral deposits in this area and the 
infrastructure projects under development ${ }^{1}$, forest areas, particularly sites with a high concentration of biodiversity or full of significant stocks of forest carbon are threatened. Unprecedented pressure on forest lands due to changes in land use could eventually fragment the forest area and have a negative impact on the survival of wildlife and on the national forest economy ${ }^{2}$.

Historically, the pressure on the forests of the Congo Basin has been comparatively low, but there are signs that this situation is unlikely to continue as pressure on forests and other ecosystems increases (Megevand, 2013). Satellite tracking data has shown that annual gross deforestation rates have doubled in the Congo Basin since 1990 (Megevand, 2013). In fact, the annual rate of net deforestation in the Congo Basin increased between the periods 1990-2000 and 2000-2005, from $0.09 \%$ to $0.17 \%$ (Ernst et al., 2010). The causes and drivers of tropical deforestation are complex, and the interaction of several direct and underlying factors has a synergistic effect on deforestation (Megevand, 2013). Indeed, deforestation in the Congo Basin is correlated with the density of populations and the expansion of subsistence activities (subsistence agriculture and harvesting of firewood) which are done to the detriment of the forest.

Many studies conducted in the TRIDOM landscape are essentially focussed on biodiversity conservation through the assessment of the wildlife in the protected areas of the three countries. No study has been yet conducted in the whole landscape to understand the importance of the land use change and its consequence on biodiversity conservation in the area.

The interest of this study is to know if the TRIDOM landscape follows the same trajectory as the whole of the Congo Basin. By signing the TRIDOM cooperation agreement, the countries have agreed to work together to preserve this forest area. This study aims to assess whether the cooperation agreement has actually contributed to the reduction of anthropogenic pressures on the forest area, by analyzing the changes in forest cover in the area before and after the signing of the agreement. It is based on the assumption that the integrity of TRIDOM is threatened by land use changes and multiple anthropogenic pressures.

\section{Material and Methods}

\subsection{Study Area}

The study area is limited to the protected border areas between Cameroon, Gabon and Congo, especially the identified areas of ecological connectivity of large fauna. To this end, the study area covers six protected areas and the contiguous forest areas. It is:

- the Nki and Boumba-Bek national parks, the Dja wildlife reserve, the Ngoyla wildlife reserve and the Ngoyla-Mintom forest massif in Cameroon;

${ }^{1}$ These are the Chole hydroelectricity dam project at the Congo-Cameroon border, the railway line project on the south-eastern ridge at the port of Kribi in Cameroon, the transnational road construction project Cameroon-Congo, Cameroon-Gabon and Congo-Gabon.

${ }^{2}$ The three TRIDOM countries are wood producers and some such as Cameroon and Congo are engaged in the REDD + process. 
- the Odzala-Kokoua national park and its northern interzone (forest concessions, Messok-Dja forest massif, Djoua-Ivindo forest) in Congo;

- the Minkébé national park and its eastern interzone (Djoua-Zadié forest, forest concessions) in Gabon.

The area of the study is estimated at $114,059 \mathrm{~km}^{2}$, which represents approximately $60 \%$ of the total area of TRIDOM. The Cameroonian part covered by the study covers an area of approximately $37,963.5 \mathrm{~km}^{2}$ and is located in the southeastern zone of the country, between the eastern regions (Haut-Nyong and Boumba and Ngoko departments) and the South (Dja and Lobo department). On the other hand, the Congolese segment dedicated to the study has an estimated area of $32,190.9 \mathrm{~km}^{2}$ and is located in the northwest of the country straddling the departments of West Cuvette (districts of Mbomo and Etoumbi), Cuvette (districts of Ntokou and Makoua) and Sangha (districts of Souanké, Sembé, Ngbala, Pikounda and Mokeko). Finally, the Gabonese segment studied covers an area of approximately $43,904.5 \mathrm{~km}^{2}$ and is located in the North-East of Gabon in the provinces of Woleu-Ntem (Haut-Ntem, Woleu and Okano departments) and Ogooué-Ivindo (departments of Ivindo and Mvoung).

Geographically, the area is located between longitudes $12^{\circ} 50^{\prime} \mathrm{E}-15^{\circ} \mathrm{E}$ and latitudes $1^{\circ} \mathrm{N}-3^{\circ} 10^{\prime} \mathrm{N}$ (Figure 1 ).

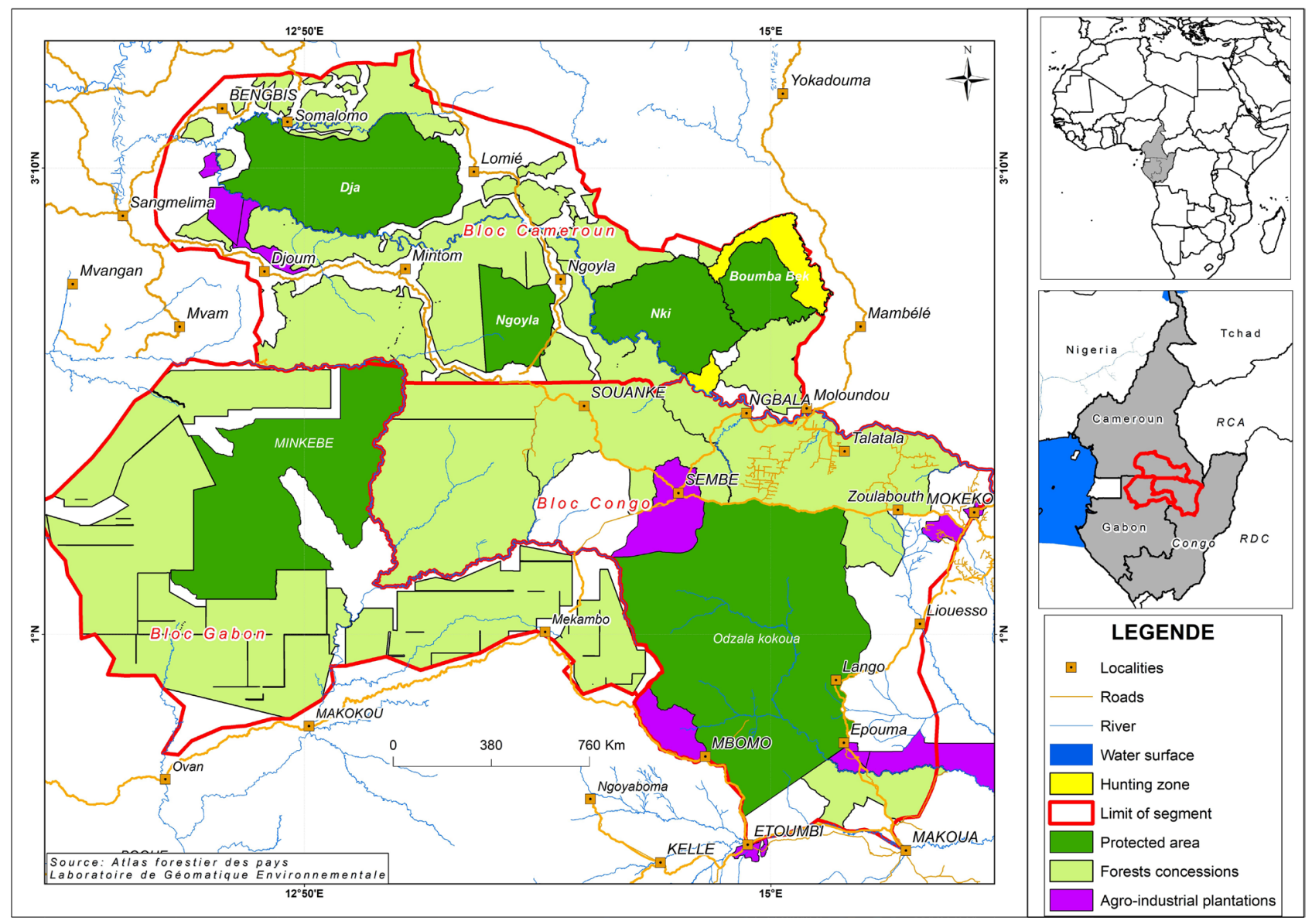

Figure 1. Location of the study area in TRIDOM. 
The relief of the area consists of a plateau with an altitude between 300 and $1000 \mathrm{~m}$ (PFBC, 2006). In several places, notably in the regions of Minkébé in Gabon and Dja in Cameroon, this plateau is punctuated by iselbergs (PFBC, 2006). Likewise, along the Gabono-Congolese border, the landscape is cut from north to south by a vertical escarpment $75 \mathrm{~km}$ long which represents a total drop of more than $100 \mathrm{~m}$.

The annual rainfall is between 1600 and $2000 \mathrm{~mm}$ (PFBC, 2006). Since the area is located roughly on the climatological equator, the climate is bimodal with two seasons of less rainfall, centered on January and July, and two rainy seasons, centered on October and April-May (PFBC, 2006). The annual average temperatures are between $23^{\circ} \mathrm{C}$ and $25^{\circ} \mathrm{C}$ in the area. Relative humidity is always high (between $70 \%$ and $80 \%$ ) with monthly maxima that can exceed $90 \%$ (Ngoufo et al., 2012).

TRIDOM landscape is entirely in an area of dense humid rain forest. Most of the landscape is covered with forests (PFBC, 2006). There are dry land forests and flooded forests. Among the dryland forests, we can recognize dense mixed semi-deciduous forests rich in Meliaceae, Ulmaceae and Sterculiacea (in particular Triplochiton scleroxylon) with an abundance of Terminalia superba and Lophira alata; sparse forests with Marantaceae, forests dominated by Gilbertiodendron dewevrei; old secondary forests and young secondary forests in Musanga (PFBC, 2006). On the other hand, the flooded forests are represented by large expanses of riparian forests with Uapaca heudelotti, swamp forests with Hallea sp., Palm groves with Phoenix reclinata (along the Mambili) and raphiales (PFBC, 2006).

The average population density in most of the landscape is of the order of 1 to 2 inhabitants $/ \mathrm{km}^{2}$, but it reaches 3 - 4 inhabitants $/ \mathrm{km}^{2}$ in the region of Djoum and Somalomo in Cameroon (PFBC, 2006). Large areas, especially in Gabon and Congo, are totally uninhabited.

\subsection{Methodology}

\subsubsection{Collection of Data}

The methodological approach adopted focuses on the use of geographic information systems and remote sensing for the production of land use maps. Due to the strong cloud cover and the unavailability of certain Landsat satellite image sheets for the periods requested in TRIDOM landscape, the satellite images from the MERIS sensor for the periods 1992, 2005 and 2018, with a resolution of 300 pixel meters were used. Indeed, the MERIS sensor is made up of five Charge Coupled Currency (CCD) networks and has a bandwidth of $1150 \mathrm{~km}$. These images acquired between the periods 1992, 2005 and 2018 made it possible to draw up the various land use maps using Envi 5.3 and Arcmap 10.8 software. The dates of acquisition of the images correspond to the period before the signing of the TRIDOM agreement, the date of signing of the agreement and the period after the signing of the said agreement by the three countries. These images were acquired during the dry season (November to March) to minimize cloud 
cover and take into account seasonality.

\subsubsection{Data Analysis}

Data analysis consisted of preprocessing the images, detecting changes and calculating the historical rate of deforestation.

- Images preprocessing

Image preprocessing was performed after data acquisition. It was structured around the following steps: geometric correction of input data to achieve a third pixel geolocation accuracy, cloud filtering, land/water reclassification and atmospheric corrections.

Then the classification of the land use was carried out. This classification aimed to transform the reflectances of the surface. The performance of this classification was based on three stages:

1) a classification algorithm for defining homogeneous land cover objects based on one (or at most two) multispectral reflectance composite (s);

2) a land cover discrimination algorithm consisting of iterative multidimensional clustering techniques;

3) a labeling procedure based on reference classifications such as regional products from Global Land Cover (GLC 2000), then adapted to MERIS. The validation was done by field visits. In this context, several sites in the Cameroonian (Ngoyla-Mintom massif, Dja and Boumba-Bek complex) and Congolese (Odzala-Kokoua complex, northern interzone) segments were visited in order to improve the quality of image processing. The aim is to compare the processed images with the large landscaped areas of the study area.

- Detection of changes

Change detection analysis involves finding the type, amount and location of land use changes over time (Yeh et al., 1996). Among the change detection approaches, post-classification comparison (PCC) was used for this study to identify changes in land cover.

The change assessment was applied to the classification results of individual images from the best performing Large Margin Separator (LMS) model to identify trajectories of change on two respective dates: 1992-2005 and 2005-2018.

The gain and loss were calculated for the three classified images (Pontius Jr. et al., 2004; Braimoh, 2006). The gain is the amount of a land use class " $i$ " that was added between time 1 and time 2, while the loss is the amount of land of the use class “ $\mathrm{j}$ ” which is lost from time 1 to time 2 .

- Calculation of the historical rate of deforestation

The annual rate of deforestation results from the ratio of the rate of deforestation over a period by the number of years between the two pivotal years of the period (Menon \& Bawa, 1997; Ramesh et al., 1997; Narendra Prasad, 1998; WRI, 1995).

As part of this study, the annual deforestation rate was calculated using the formula proposed by Puyravaud (2002). It is presented by the following relation: 


$$
\phi=-\frac{1}{t_{2}-t_{1}} \operatorname{in} \frac{A_{2}}{A_{1}} * 100
$$

With:

$t_{1}$ dates to year 1 and $t_{2}$ dates to year 2 ;

$\phi$ : Annual deforestation rate over the period between $t_{1}$ and $t_{2}$ in [\%];

$A_{1}$ : Forest area in year $t_{1} ; A_{2}$ : forest area in year $t_{2}$;

Ln: Neperian logarithm.

\section{Results}

\subsection{Types of Land Use by Period $(1992,2005,2018)$}

Figures 2-4 below show the different land use maps of the study area for the periods 1992, 2005 and 2018.

Following Table 1 shows the trends in land use types in 1992, 2005 and 2018.

From this table, it appears that the TRIDOM landscape is mainly occupied by

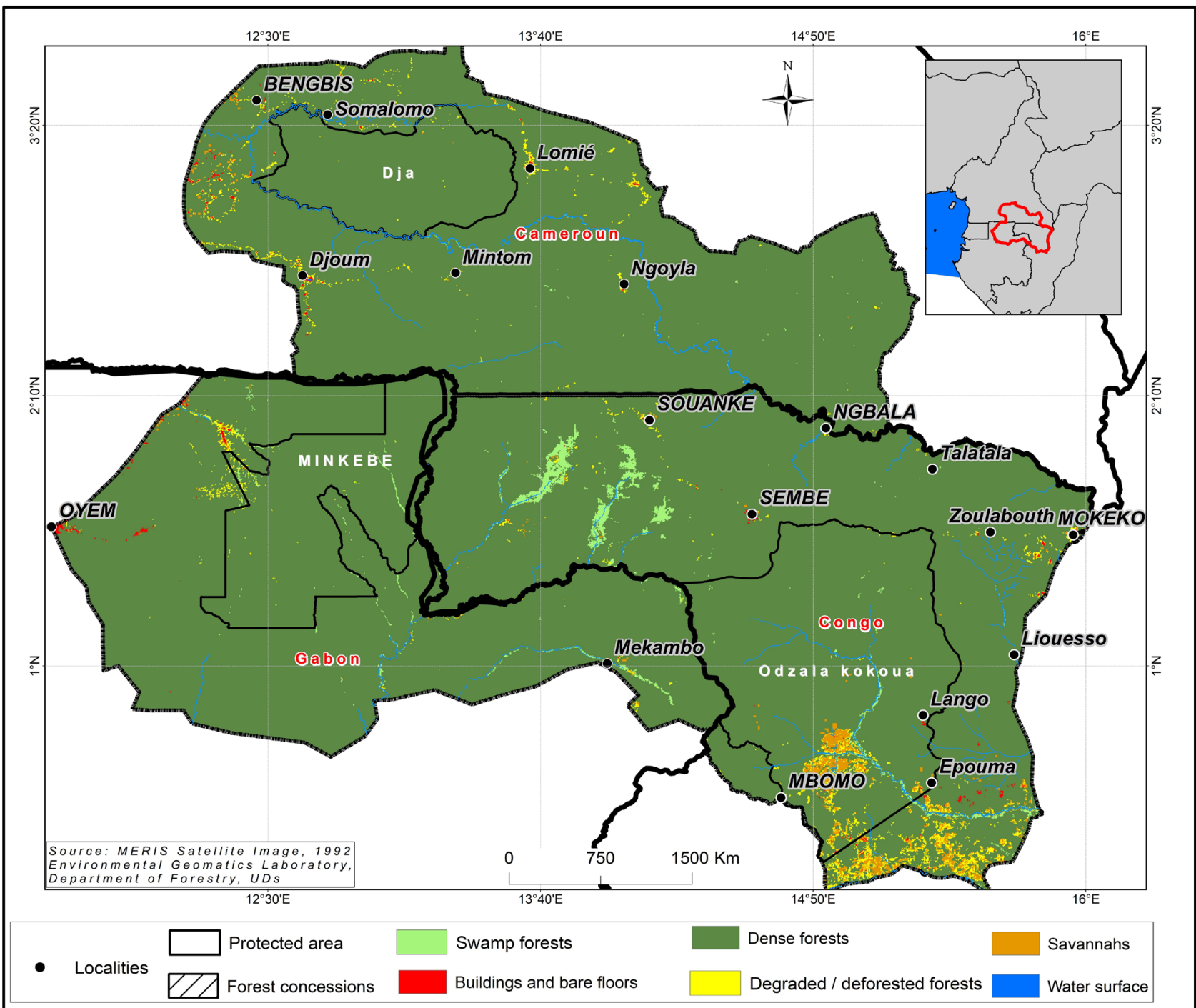

Figure 2. Land use in the TRIDOM area in 1992. 


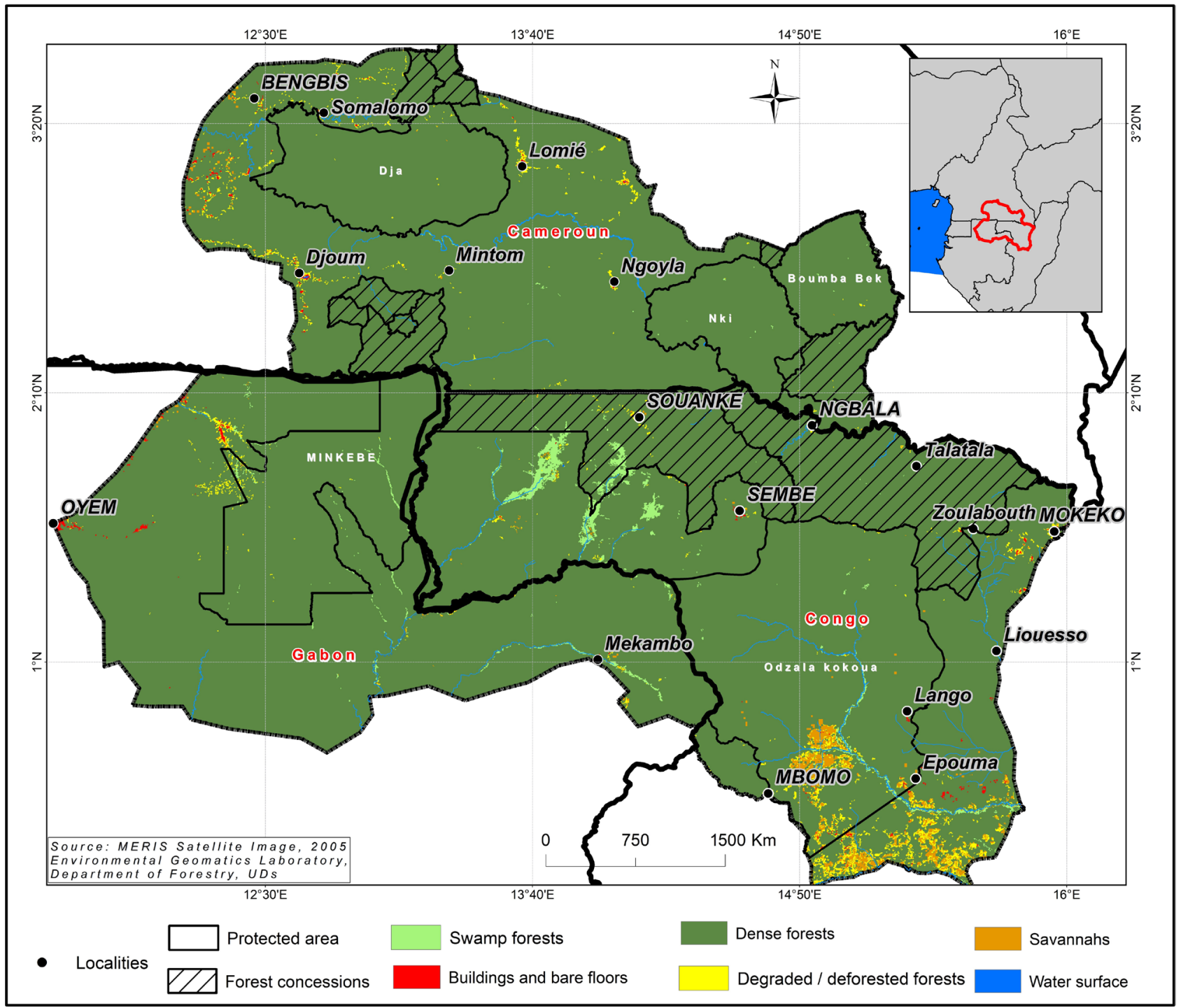

Figure 3. Land use in the TRIDOM area in 2005.

Table 1. Land cover areas in the TRIDOM landscape between 1992 and 2018.

\begin{tabular}{ccccccc}
\hline Land use & 1992 & $\%$ & 2005 & $\%$ & 2018 & $\%$ \\
\hline Buildings and bare floors & $22,847.38$ & 0.20 & $31,512.36$ & 0.28 & $34,392.61$ & 0.30 \\
Degraded/deforested forests & $121,262.40$ & 1.06 & $138,949.13$ & 1.22 & $154,848.41$ & 1.36 \\
Dense forests & $11,065,874.78$ & 97.02 & $11,032,154.28$ & 96.72 & $11,008,857.46$ & 96.52 \\
Swamp forests & $111,987.75$ & 0.98 & $111,716.65$ & 0.98 & $111,522.97$ & 0.98 \\
Savannahs & $77,667.03$ & 0.68 & $87,903.88$ & 0.77 & $92,511.34$ & 0.81 \\
Water surface & 6250.74 & 0.05 & 3653.77 & 0.03 & 3757.30 & 0.03 \\
Grand total & $11,405,890.07$ & 100 & $11,405,890.07$ & 100 & $11,405,890.07$ & 100 \\
\hline
\end{tabular}




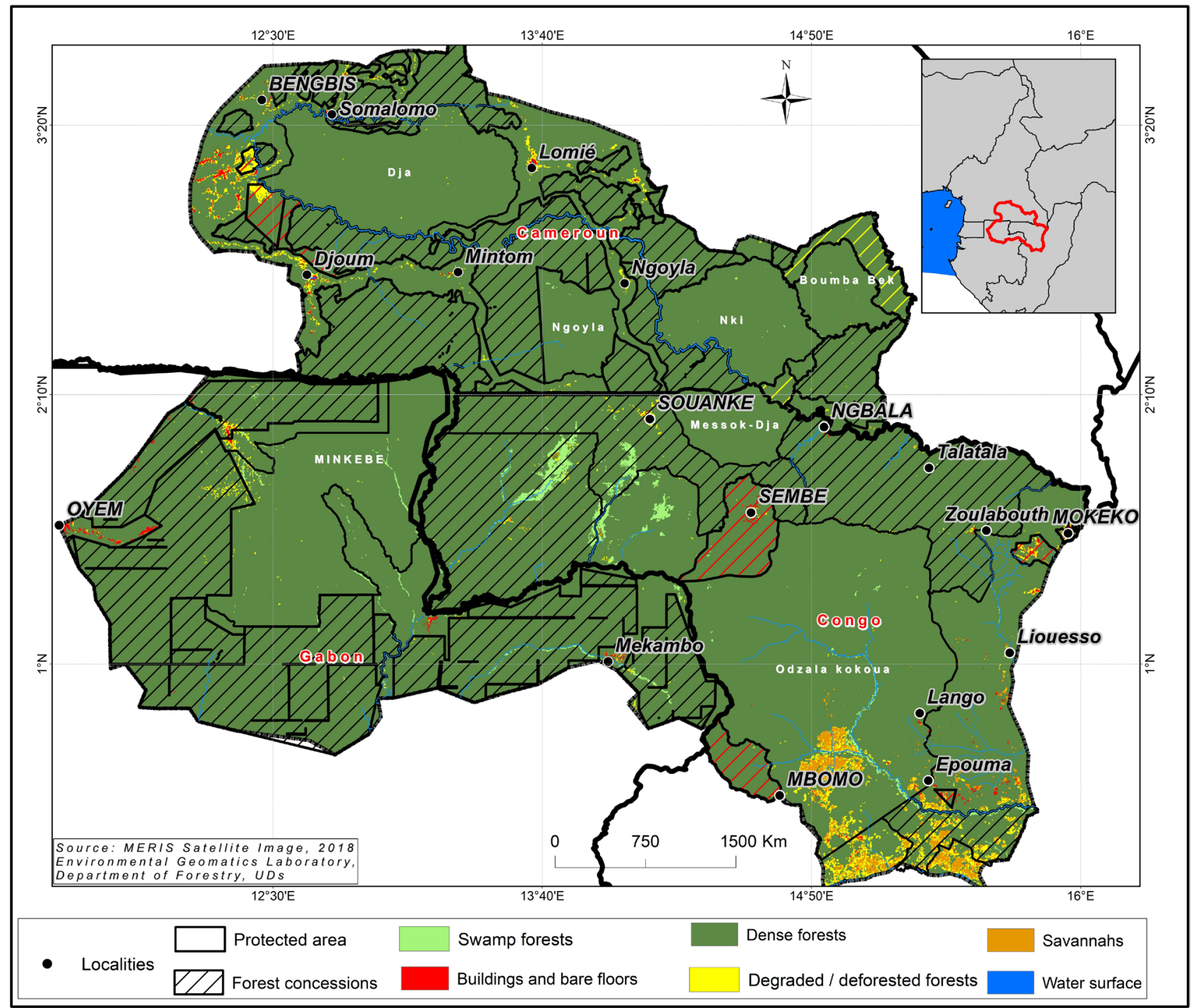

Figure 4. Land use in the TRIDOM area in 2018.

dense forests which represent $97.02 \%, 96.72 \%$ and $96.52 \%$ respectively in 1992 , 2005 and 2018 of the entire forest massif. Then, degraded/deforested forests and savannas which would correspond to cultivation areas and fallow land only represent respectively $1.06 \%$ and $0.68 \%$ of the landscape in 1992 . This proportion in 2005 is respectively $1.22 \%$ and $0.77 \%$, whereas in 2018 , it is respectively $1.36 \%$ and $0.81 \%$ of the massif.

\subsection{Land Use Changes from 1992 to 2018}

\subsubsection{Change in Land Use between 1992 and 2005}

The map below shows the land use change hotspot areas (Figure 5).

The types of land use change are summarized in Table 2 below.

From this table, the landscape of TRIDOM has not changed much in the period leading up to the signing of the cooperation agreement. In fact, dense forests occupy a very large area and this area remained unchanged between 1992 


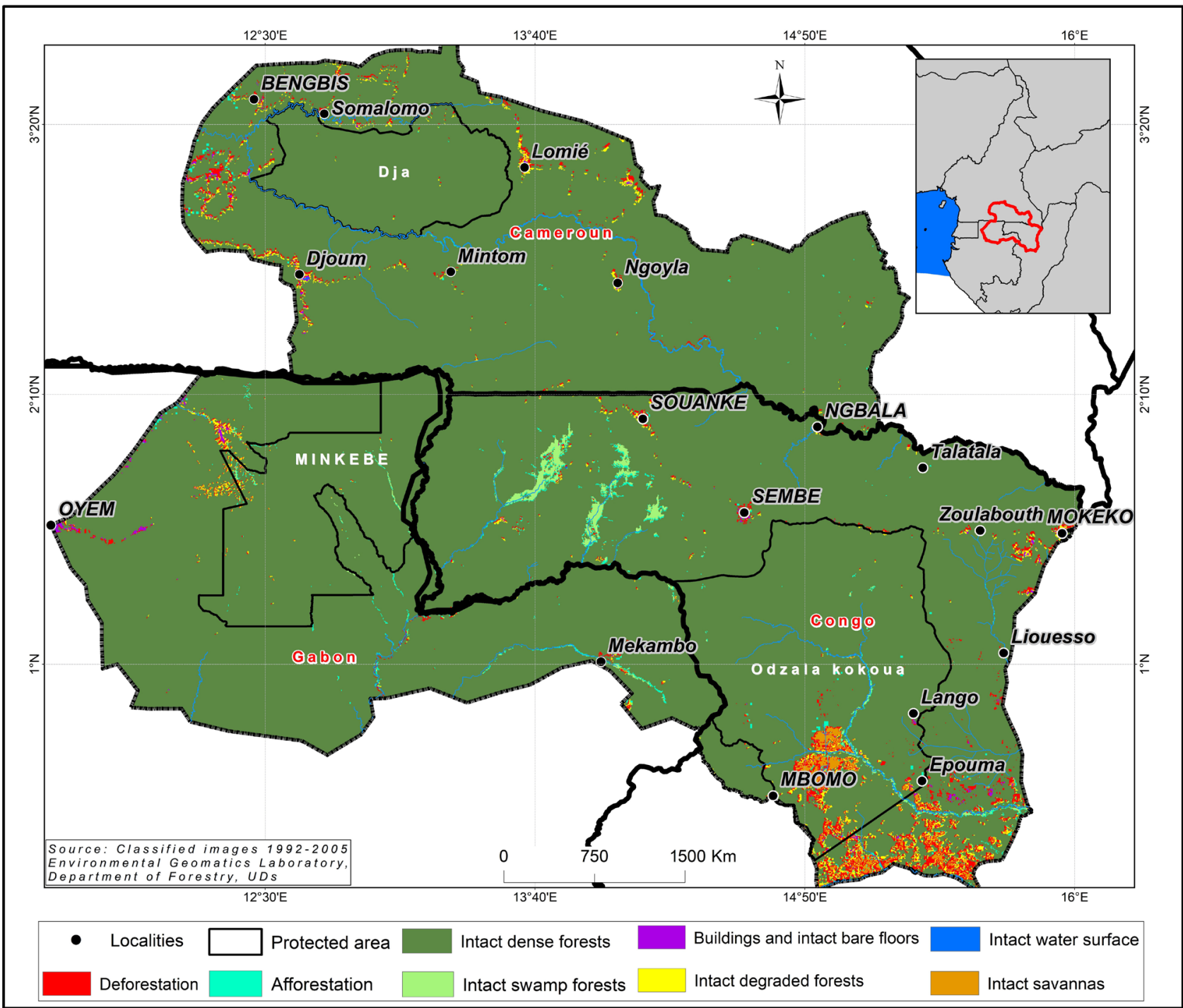

Figure 5. Hotspot area of land use change between 1992 and 2005.

Table 2. Types of land use changes between 1992 and 2005.

\begin{tabular}{ccccc}
\hline & & Changes between 1992-2005 & Description of changes \\
\hline Type of changes & Area (ha) & $\%$ & Conversion of degraded areas into forests \\
Afforestation & $63,669.47206$ & 0.56 & No changes \\
Buildings and intact bare floors & $22,344.78293$ & 0.20 & No changes \\
Deforestation/Degradation & $168,060.8601$ & 1.48 & Deforestation/degradation of forests in plantations, habitation, bare soils and savannas \\
Intact degraded forests & $106,257.0622$ & 0.93 & No changes \\
Intact swamp forests & $64,910.21995$ & 0.57 & No changes \\
Intact dense forests & $10,898,764.21$ & 95.86 & No changes \\
Intact savannas & $39,372.24043$ & 0.35 & No changes \\
Intact water surface & 5537.22104 & 0.05 & \\
Grand total & $11,368,916.07$ & 100 & \\
\hline
\end{tabular}


and 2005 . They represent $95.86 \%$ of the total area of the landscape. It should also be noted that during the period there was a slight conversion of degraded areas into forest, or $0.56 \%$ of afforestation. On the other hand, deforestation and degradation occupy $1.48 \%$ of the total area of the landscape. The rate of deforestation and degradation is still low in the landscape. However, it is observed that deforested and degraded areas are much more concentrated around the protected areas of the three countries, which poses a serious threat to the maintenance of integrity and the preservation of biodiversity in these protected areas.

\subsubsection{Change in Land Use between 2005 and 2018}

The following map shows the hotspot areas of land cover change during the period 2005 and 2018 (Figure 6).

The types of land use change are summarized in Table 3 below.

From the table, it can be seen that the landscape of TRIDOM has not experienced a significant change in land use during the period after the signing of the

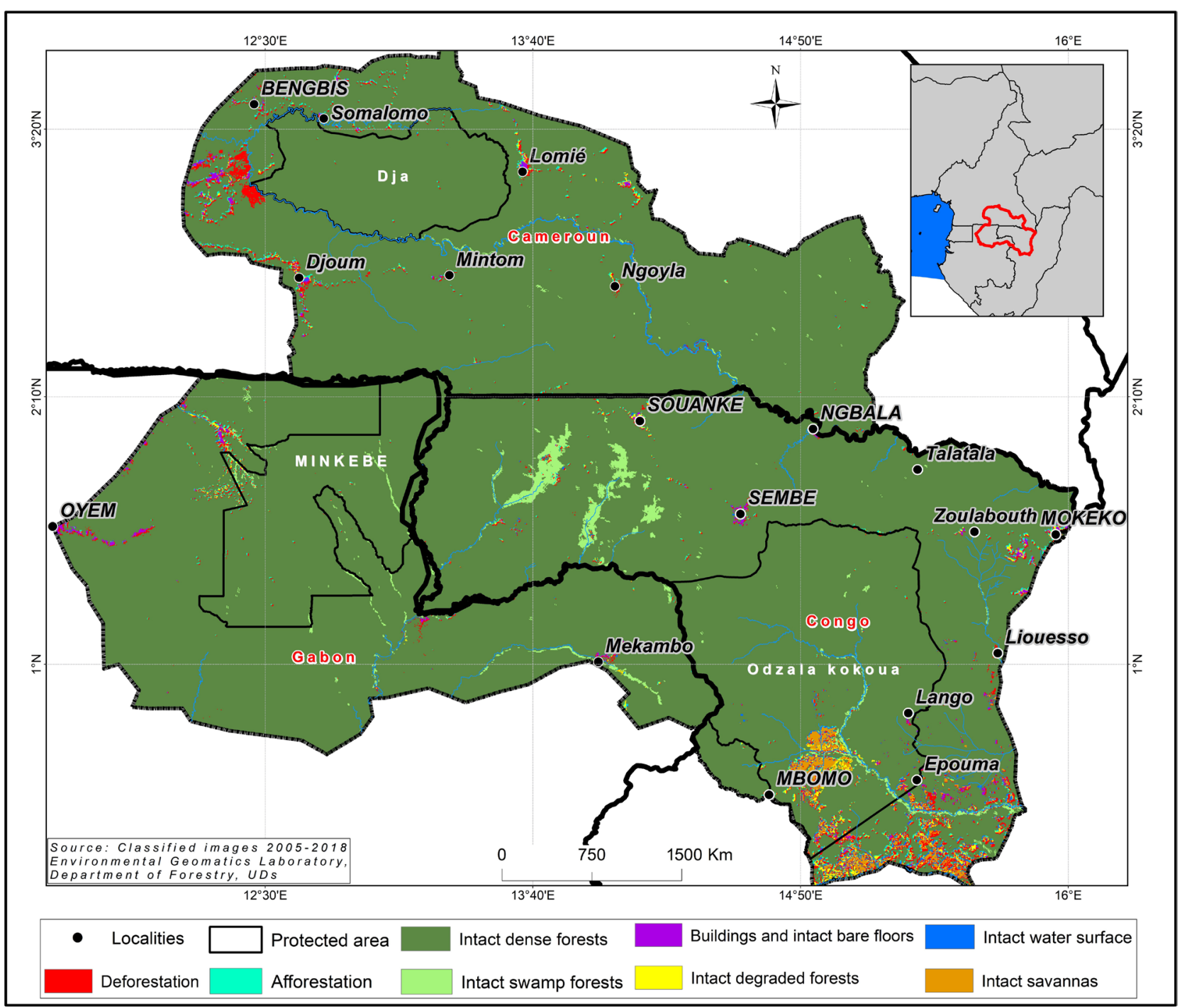

Figure 6. Hotspot area of land use change between 2005 and 2018. 
Table 3. Types of land use changes between 2005 and 2018.

\begin{tabular}{cccc}
\hline & \multicolumn{4}{c}{ Change between 2005-2018 } \\
\hline Type of changes & Area (ha) & $\%$ & Description of changes \\
\hline Afforestation & $56,855.18168$ & 0.50 & Conversion of degraded areas into forests \\
Buildings and intact bare floors & $37,361.12316$ & 0.33 & No changes \\
Deforestation/Degradation & $141,125.5946$ & 1.24 & $\begin{array}{c}\text { Deforestation/degradation of forests in } \\
\text { plantations, habitation, bare soils and savannas }\end{array}$ \\
Intact degraded forests & $151,011.1009$ & 1.33 & No changes \\
Intact swamp forests & $55,937.67698$ & 0.49 & No changes \\
Intact dense forests & $10,833,971.6$ & 95.29 & No changes \\
Intact savannas & $54,027.07219$ & 0.48 & No changes \\
Intact water surface & $38,626.72418$ & 0.34 & No changes \\
Grand total & $11,368,916.07$ & 100 & \\
\hline
\end{tabular}

cooperation agreement. Dense forests still occupy a significant area of the landscape and this area has not changed much compared to the period before the agreement was signed. They represent $95.29 \%$ of the total area of the landscape, compared to $95.86 \%$ in the previous period. The other not insignificant fact is the continuation of the phenomenon of recolonization of areas degraded by the forest. This afforestation represents $0.50 \%$ of the landscape area. Deforestation and degradation also continued, but at a rate of $1.24 \%$, slightly lower than in the period 1992-2005. The rate of deforestation and degradation has therefore remained low in the landscape, but pressure has increased around the Dja Biosphere Reserve and Odzala-Kokoua National Park with the development of agro-industrial plantations.

\subsection{Historical Rate of Deforestation from 1992 to 2018}

The following tables show respectively the forest areas lost from 1992 to 2018 and the annual rates of deforestation during this period (Table $4 \&$ Table 5).

Table 4. Forest areas and forest loss.

\begin{tabular}{cccccc}
\hline \multirow{2}{*}{ Land use } & \multicolumn{3}{c}{ Area (ha) } & \multicolumn{2}{c}{ Lost surfaces } \\
\cline { 2 - 5 } & 1992 & 2005 & $\mathbf{2 0 1 8}$ & $\mathbf{1 9 9 2 - 2 0 0 5}$ & $\mathbf{2 0 0 5 - 2 0 1 8}$ \\
\hline Dense forests & $11,065,874.78$ & $11,032,154.28$ & $11,008,857.46$ & $-33,720.49$ & $-23,296.82$ \\
Swamp forests & $111,987.75$ & $111,716.65$ & $111,522.97$ & -271.10 & -193.68 \\
Grand total & $11,177,862.52$ & $11,143,870.93$ & $11,120,380.43$ & & \\
\hline
\end{tabular}

Table 5. Annual rate of deforestation between 1992 and 2018.

\begin{tabular}{ccc}
\hline Types of forests & Rate (1992-2005) & Rate (2005-2018) \\
\hline Dense forests & 0.023 & 0.016 \\
Swamp forests & 0.019 & 0.013 \\
Total & 0.042 & 0.030 \\
\hline
\end{tabular}


During the period 1992-2005, the loss of dense forests is estimated at 33, 720.49 ha and that of swamp forests is 271.10 ha, which represents an annual deforestation rate of $0.023 \%$ and $0.019 \%$ respectively. For the period $2005-2018$, the loss of dense forests is estimated at $23,296.82$ ha and that of swamp forests is 193.68 ha, i.e. an annual deforestation rate of $0.016 \%$ and $0.013 \%$ respectively. The estimated annual global deforestation rate is $0.042 \%$ and $0.030 \%$ for both periods.

\section{Discussion}

The cross-border landscape of TRIDOM is one of the relatively intact forest areas of the Congo Basin. There are still large areas of dense forests, as illustrated by the images on land use types from 1992, 2005 and 2018. Indeed, from 1992 to 2018, the proportion of the territory occupied by dense forests has remained important, despite the threats to which this forest massif is confronted, due to the presence of natural resources (fauna, wood, minerals, land reserve for agriculture, etc.). Dense forests represent $95.86 \%$ and $95.29 \%$ of the total landscape area respectively during the periods 1992-2005 and 2005-2018. The forest cover therefore remained more or less stable during these two periods. However, from the start of the 1990s, this massif was subject to pressure from local, national and even foreign actors, notably with the proliferation of artisanal mining sites in the three countries and subsistence activities such as shifting on burns cultivation and the harvest of firewood. These subsistence activities, as pointed out by Megevand (2013), have contributed to deforestation and forest degradation in the massif.

During the period preceding the signing of the Cooperation Agreement (19922005), a large part of the TRIDOM landscape was not secure in the three countries. Cameroon has only one protected area (Dja fauna reserve) and a few forest concessions; Similarly, Congo has only two protected areas (Odzala-Kokoua National Park and Lossi gorilla sanctuary). Deforestation and degradation occupies $1.48 \%$ of the total landscape area during this period. On the other hand, for the post-signing period of the cooperation agreement (2005-2018), deforestation and degradation continued, but at a slightly lower rate $(1.24 \%)$ than in the period 1992-2005. During this phase of post cooperation agreement, many measures were taken by the three countries to secure their respective massifs. Thus, new protected areas have been created and classified in Cameroon (Nki national park, Boumba-Bek national park and Ngoyla wildlife reserve), as well as areas assigned to forest and wildlife management have been classified (areas of hunting interests, forestry concessions, communal forests, etc.). Also, Congo has created a new protected area (Ntoukou-Pikounda national park) and is committed to the creation of another protected area at its northern border with Cameroon (Messok-Dja, border to Nki national park in Cameroon), just as forest concessions have been classified and awarded (Jua-Ikié, Talatala, Karagoua). Finally,

Gabon has classified and allocated new forest concessions in the large forest 
massif of Minkébé. Also, with regard to the legal framework of the three countries, the forest concessionaires have the obligation to draw up management plans and to respect exploitation standards to guarantee the rational and sustainable exploitation of the forest resources of their respective concessions. These management plans are however faced with pitfalls linked to the non-compliance with the provisions of the said management plans by the forest concessionaires. At the operational level, over the period 2005-2018, countries strengthened their surveillance and anti-poaching systems. This is the case of Gabon, which, thanks to its reinforced surveillance system, succeeded in expelling in 2011 the illegal traffickers of gold and other resources installed inside the Minkébé National Park.

Although a comparative evaluation of the dynamics of deforestation in a similar forest area, but not subject to a cooperation agreement has not been carried out, it is noted that the annual rate of deforestation for the period after the signing of the cooperation agreement (2005-2018) decreased compared to the one before the signing of the agreement (1992-2005). It is $0.030 \%$ over the period 2005-2018, while in 1992-2005, this rate was $0.042 \%$. This reduction seems to be linked to the above-mentioned measures taken by the governments of the three countries to secure and sustainably manage their respective forest areas.

The rate of deforestation in the TRIDOM area has remained very low overall during the period under study. This annual rate of overall deforestation for the two periods is indeed lower compared to the annual rate of deforestation for the Congo Basin estimated at $0.09 \%$ and $0.17 \%$ respectively for the period $1990-2000$ and 2000-2005 (Ernst et al., 2010). It is also well below the annual deforestation rate estimated at $1.064 \%$, by Tanougong (2019) in the inter-communal forest of Belabo-Doumé and Diang in eastern Cameroon between 2000-2018. The low deforestation rate in the TRIDOM landscape seems to be linked, in addition to the sustainable management measures taken by the authorities of the three countries, to the isolation of the forest massif in the three countries which makes it difficult to access on the one hand and to the low density of populations in this area on the other hand.

\section{Conclusion}

This study shows that there are six land use classes in the TRIDOM transboundary landscape, namely dense forests, degraded and deforested forests, savannas, swamp forests, buildings and bare soils, water surfaces. Degraded or deforested forests and savannas most often correspond to cultivated areas and fallow land. It is noted that the landscape of TRIDOM has not experienced a significant change in land use during the period after the signing of the cooperation agreement. Dense forests still occupy a significant area of the landscape and this area has not changed much compared to the period before the signing of the agreement. They represent $95.29 \%$ of the total area of the landscape, compared to $95.87 \%$ in the period leading up to the signing of the agreement. Deforestation 
rates in the TRIDOM area are generally very low during the period under study. Indeed, the estimated annual global deforestation rate is $0.042 \%$ and $0.030 \%$ respectively for the period 1992-2005 (before signing of the agreement) and the period 2005-2018 (after signing of the agreement). These low rates of deforestation seem to be due to the measures taken to secure and sustainably manage the massif taken by the three countries, the low population density in this area and the still difficult level of accessibility of a large part of the massif.

However, in view of the development demands of these countries, the pressure and threats are likely to increase in the coming years in TRIDOM. To prevent this pressure from leading to massive deforestation, countries must develop and/or finalize their land use plans in order to permanently secure the TRIDOM forest estate. Therefore, they must strengthen their monitoring mechanisms for the implementation of forest concession management plans so that the orientations of these plans are scrupulously respected by forest concessionaires. Finally, given the biodiversity conservation objective assigned to the TRIDOM area, countries must establish additional legal provisions that can guarantee the sustainable management of forest concessions, such as forest certification. Although certification is a market instrument, it has the advantage of allowing sustainable management that can guarantee the maintenance of all the functions of the forest (economic, social and ecological).

\section{Acknowledgements}

Our field investigations, particularly in the TRIDOM segments of Cameroon and Congo, were made possible thanks to the support of several organizations namely African Wildlife Foundation (AWF), the Cameroon Office of the World Wide Fund for Nature (WWF-Cameroon), the Espace Tridom Interzone Congo program (WWF-ETIC) and the Odzala Foundation. We are very grateful for their logistical support provided.

\section{Conflicts of Interest}

The authors declare no conflicts of interest regarding the publication of this paper.

\section{References}

Braimoh, A. K. (2006). Random and Systematic Land-Cover Transitions in Northern Ghana. Agriculture, Ecosystems \& Environment, 113, 254-263. https://doi.org/10.1016/j.agee.2005.10.019

De Wachter, P., Malonga, R., Moussavou, M. B. L., Nishibara, T., Nzooh, Z., \& Usongo, L. (2008). Dja-Odzala-Minkébé (TRIDOM). In C. de Wasseige, D. Devers, P. de Mercken, R. Eba'a Atyi, R. Nasi, \& Ph. Mayaux (Eds.), Les forêts du bassin du Congo-Etat des forêts 2008, Office des publications de l'Union Européenne, 2009.

Ernst, C., Verhegghen, A., Mayaux, Ph., Hansen, M., \& Defourny, P. (2010). Cartographie du Couvert Forestier et des Changements du Couvert Forestier en Afrique Centrale. In C. de Wasseige, P. de Marcken, N. Bayol, F. Hiol Hiol, Ph. Mayaux, B. Desclée, R. Nasi, A. Billand, P. Defourny, \& R. Eba'a Atyi (Eds.), Les forêts du bassin du Congo-Etat des 
forêts 2010, Office des publications de l'Union Européenne, 2012.

Megevand, C. (2013). Dynamiques de déforestation dans le bassin du Congo: Réconcilier la croissance éconolique et la protection de la forêt. Washington, DC: World Bank, $179 \mathrm{p}$. https://doi.org/10.1596/978-0-8213-9827-2

Menon, S., \& Bawa, K. S. (1997). Applications of Geographic Information System, Remote-Sensing, and Landscape Ecology Approach to Biodiversity Conservation in the Western Ghats. Current Science, 73, 134-145.

Narendra Prasad, S. (1998). Conservation Planning for the Western Ghats of Kerala. II. Assessment of Habitat LOSS and Degradation. Current Science, 75, 228-235.

Ngoufo, R., Njoumemi, N., \& Parren, M. (2012). État des lieux de la situation économique, écologique et sociale actuelle de l'espace Camerounais du TRIDOM. Tropenbos International-Programme du bassin du Congo, Wageningen, Pays-Bas, 145 p.

PFBC (2006). Les forêts du bassin du Congo: Etat des forêts 2006. 256 p.

Pontius Jr., R. G., Shusas, E., \& McEachern, M. (2004). Detecting Important Categorical Land Changes While Accounting for Persistence. Agriculture, Ecosystem and Environment, 101, 251-268. https://doi.org/10.1016/j.agee.2003.09.008

Puyravaud, J. P. (2002). Standardizing the Calculation of the Annual Rate of Deforestation. Forest Ecology and Management, 177, 593-596.

https://doi.org/10.1016/S0378-1127(02)00335-3

Ramesh, B. R., Menon, S., \& Bawa, K. S. (1997). A Vegetation Based Approach to Biodiversity Gap Analysis in the Agastyamalai Region, Western Ghats, India. AMBIO A Journal of the Human Environment, 26, 536-539.

Tanougong, A. D. (2019). Modélisations prédictives des changements d'occupation des sols à l'horizon 2035: cas du massif forestier intercommunal de Bélabo-Doumé-Diang dans la région de l'Est-Cameroun. Mémoire de Master 2 Gestion des Ressources Naturelles, Département de Foresterie-Université de Dschang, 121 p.

WRI (1995). World Resource 1994-1995. Delhi, WRI/Oxford University Press.

Yeh, A., Gar, A., \& Xia, L. (1996). Urban Growth Management in Pearl River Delta: An Integrated Remote Sensing and GIS Approach. ITC Journal, 1, 77-78. 